\title{
MPNST after Radiosurgery: A Report and Review of the Literature
}

\author{
Albert Tu, Roy Ma, John Maguire, Ryojo Akagami
}

\begin{abstract}
Objective: To report an unusual case of malignant degeneration in a ganglioneuroma of the jugular foramen post stereotactic radiosurgery as well as to systematically review the pertinent literature involving radiosurgery associated malignancies. Background: Ganglioneuromas are uncommon lesions of the peripheral nervous system and infrequently reported in the head and neck region. There have been no previously described cases of ganglioneuromas occurring in the jugular foramen. Malignant degeneration of these lesions is rarely described, especially in the context of radiosurgery. Radiosurgery associated malignancies overall are exceptionally rare and only a limited number of cases have been reported.Results/Conclusions: We describe a case of a ganglioneuroma occurring in the jugular foramen and mimicking the appearance of a jugular foramen schwannoma. This lesion underwent stereotactic radiosurgery and developed a delayed degeneration into a malignant nerve sheath tumor. The occurrence of ganglioneuroma in this region has not been previously described and presumed malignant degeneration is even rarer. This case highlights a previously understated risk associated with stereotactic radiation treatments. To date, 33 previous cases of stereotactic radiosurgery associated malignancies have been reported. We review the pertinent details of these cases. We caution that as follow up periods and awareness increases, reports such as this may become increasingly common.
\end{abstract}

RÉSUMÉ: Tumeurs malignes des gaines nerveuses périphériques après la radiochirurgie : à propos d'un cas et revue de littérature. Objectif : Nous rapportons un cas inusité de dégénérescence maligne dans un ganglioneurome du trou déchiré postérieur après la radiochirurgie stéréotaxique ainsi qu'une revue systématique de la littérature pertinente sur la radiochirurgie associée à des cancers. Contexte : les ganglioneuromes sont des lésions rares du système nerveux périphérique qui sont rapportées exceptionnellement dans la région de la tête et du cou. Il n'existe pas de cas décrit antérieurement de ganglioneurome situé dans le trou déchiré postérieur. Une dégénérescence maligne de ces lésions est rarement décrite, spécialement dans le contexte de la radiochirurgie. Globalement, les cancers associés à la radiochirurgie sont extrêmement rares et un très petit nombre de cas ont été rapportés. Résultats / Conclusions : Nous décrivons un cas de ganglioneurome situé dans trou déchiré postérieur imitant l'aspect d'un schwannome du trou déchiré postérieur. Cette lésion a été traitée par radiochirurgie stéréotaxique et a par la suite dégénéré en tumeur maligne de la gaine nerveuse de Schwann. Aucun ganglioneurome de cette région n'a été décrit antérieurement et une présumée dégénérescence maligne est encore plus rare. Ce cas illustre un risque sous-estimé jusqu'ici associé aux traitements par irradiation stéréotaxique. À ce jour, 33 cas de cancers associés à la radiochirurgie stéréotaxique ont été rapportés. Nous revoyons les détails pertinents de ces cas. Nous soulignons que, à mesure que la période de suivi et que les connaissances augmentent, les rapports comme le nôtre pourraient devenir plus fréquents.

Can J Neurol Sci. 2014; 41: 74-81

The jugular foramen is one aperture of the skull base that transmits numerous nervous and vascular structures. Tumors of this area comprise less than $1 \%$ of all central nervous system oncology and cause symptoms owing to compression of adjacent structures $^{1}$. Malignant lesions are $\operatorname{rare}^{1}$. Owing to the challenging surgical approach and eloquence of local anatomy, radiosurgery is often used in this vicinity. However radiation treatments are not without risk including malignant transformation. Here we document the first known ganglioneuroma occurring within the jugular foramen ${ }^{1,2}$ with subsequent malignant degeneration post radiosurgical treatment and review previous cases of radiosurgery associated malignancy.

\section{CASE}

A 34-year-old female presented with left sided retroauricular headache, voice change, dysphagia, and pain of her left shoulder. Examination revealed a diminished left gag reflex, rightward palatal deviation, and left sternocleidomastoid atrophy. Over the next eight weeks, she developed left sided retroauricular headache with ipsilateral trapezius weakening and wasting. Medical and family history was non contributory with no report of neurocutaneous syndromes. Imaging revealed a uniformly enhancing lesion with enlargement and expansion of the left jugular foramen (Imaging unavailable). The lesion was measured to be $15 \times 20 \times 12 \mathrm{~mm}$ and hypo attenuating on

From the University of British Columbia, Faculty of Medicine (AT, RA); Department of Radiation Oncology (RM), BC Cancer Agency; Division of Neurosurgery (AT, RA), Department of Pathology (JM), Vancouver General Hospital, Vancouver, British Columbia, Canada.

Received June 10, 2013. Final Revisions Submitted July 31, 2013. Correspondence to: Ryojo Akagami, Division of Neurosurgery, Gordon and Leslie Diamond Health Care Centre, 8109- 2775 Laurel Street DHCC, Vancouver General Hospital, Vancouver, British Columbia, V5Z 1M9, Canada. Email: ryojo.akagami@vch.ca. 


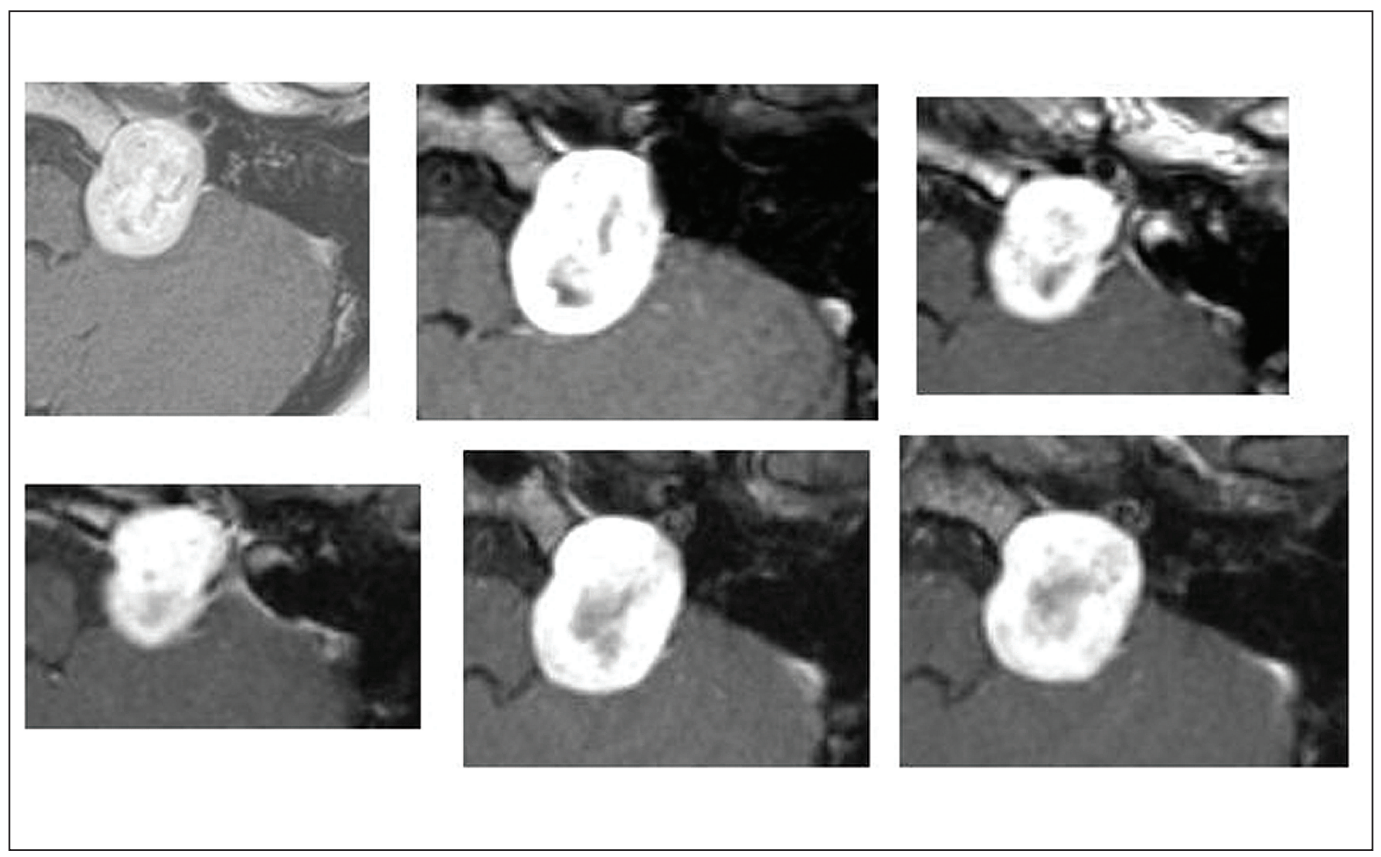

Figure 1: Interval MR imaging showing the lesion (highlighted by arrow) between July 2000 March 2004. Figure in top left corner corresponds to 12 months (July 2000) following initial treatment of radiosurgery. Middle upper figure is 15 months (October 2000) after initial treatment. Right upper figure demonstrates the lesion 21 months (April 2001) later. Subsequent figures (left to right) are taken at approximately 1 year intervals thereafter (Figure 4, March 2002; Figure 5, April 2003; Figure 6, March 2004). Note the dimensions of the lesion in July $2000(29 \times 24$ $\left.\begin{array}{lll}x & 21 & \mathrm{~mm}\end{array}\right)$ (transverse $x$ longitudinal $x$ height) compared to following images $(26 \times 18 \times 19$ $\mathrm{mm}$ ) - there is noted ongoing stability in size. Measurements are taken at approximately the same level. Note that different sequences are displayed in order to best display constancy of features.

computed tomogram (CT) while $\mathrm{T} 1$ and $\mathrm{T} 2$ iso intense on magnetic resonance imaging (MRI). There was extension into the subarachnoid space. An angiogram was performed demonstrating hypervascularity of the lesion. These features were most suggestive of a jugular foramen schwannoma or paraganglioma and a referral to the radiation oncology service was made.

The patient underwent stereotactic radiosurgery via a LINAC irradiation system. She received a dose of $12 \mathrm{~Gy}$ at the $50 \%$ isodose line using two isocentres. The dose of radiation was determined by the possibility that the lesion represented a schwannoma and would require a higher dose than used in treating paragangliomas. The lesion measured $21 \times 14 \mathrm{~mm}$ at its greatest dimensions at the time of treatment. There were no complications during the post treatment period.

Repeat imaging at 12 months post-treatment demonstrated a transient increase in the size of the lesion although in keeping with expected post radiation changes. Subsequent radiographic and clinical follow up remained stable. (Figure 1)

Seven years after treatment, routine imaging demonstrated a dramatic decrease in the volume of the lesion (Figure 2) without any corresponding clinical change. Twenty months later however, the patient represented acutely with progressive headache, insensate tongue and speech impairment. Imaging revealed a substantial increase in the size of the tumor (Figure 3). A decision was made to resect the lesion urgently (Figure 4). Intraoperatively, the lesion was noted to be grey and soft in texture with numerous lobulations and loculations of unusual appearance. There was also significant intralesional hemorrhage and edema. Its appearance was not felt to be in keeping with a typical schwannoma or paraganglioma. An intraoperative frozen section confirmed a preliminary diagnosis of a spindle cell lesion and a gross total resection was obtained.
Post operatively, the patient noted some recovery from her symptoms and was discharged from hospital; however, by nine weeks did represent with headaches and obstructive hydrocephalus. A recurrent mass was found with invasion into the cerebellum (Figure 5). Given the rapidity of her recurrence

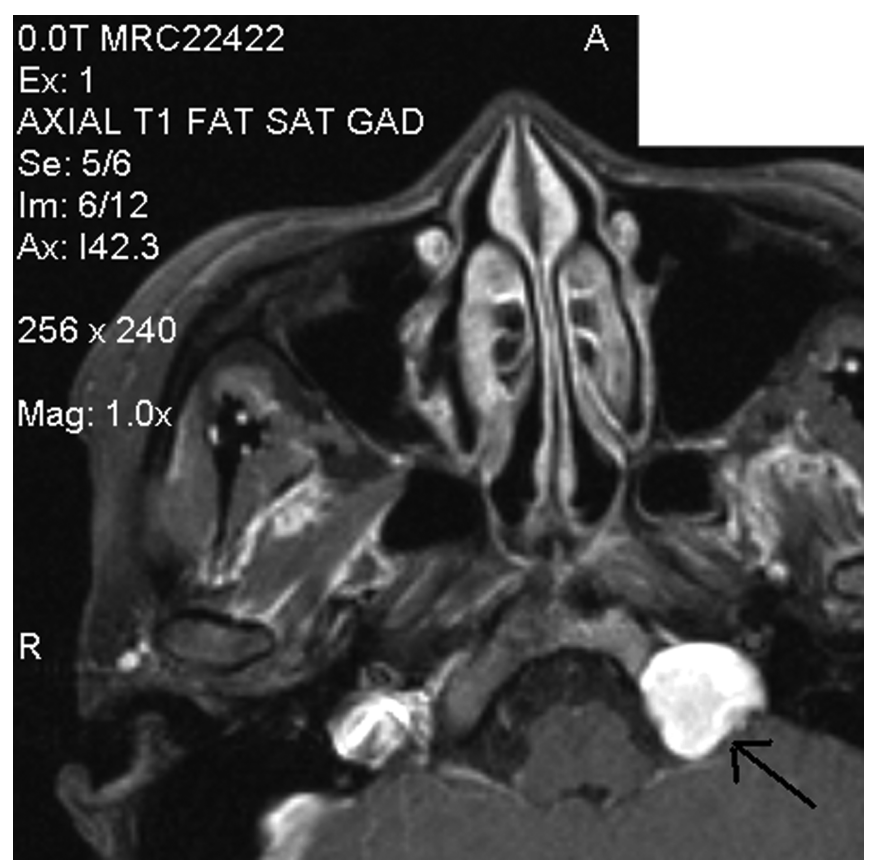

Figure 2: Interval MR imaging showing decrease in size of lesion compared. Lesion measures $19 \times 17 \times 21 \mathrm{~mm}$. Image was taken in April 2006. 




Figure 3: MRI (left) and CT (right) images showing significantly enlarged. Note surrounding edema and shift of brainstem. Lesion measures $24 \times 20 \times 21 \mathrm{~mm}$. Image was taken in December 2007.

and the pathology of the lesion, the patient was referred for palliative radiation therapy. She remained very unwell and died several months later.

\section{Histology/Pathology}

Sections from the lesion demonstrated a spindle cell tumor with areas of moderate to intense cellularity. Small cell tumor elements were also seen within the more cellular regions. Areas of necrosis were seen. Nuclear pleomorphism was moderate to

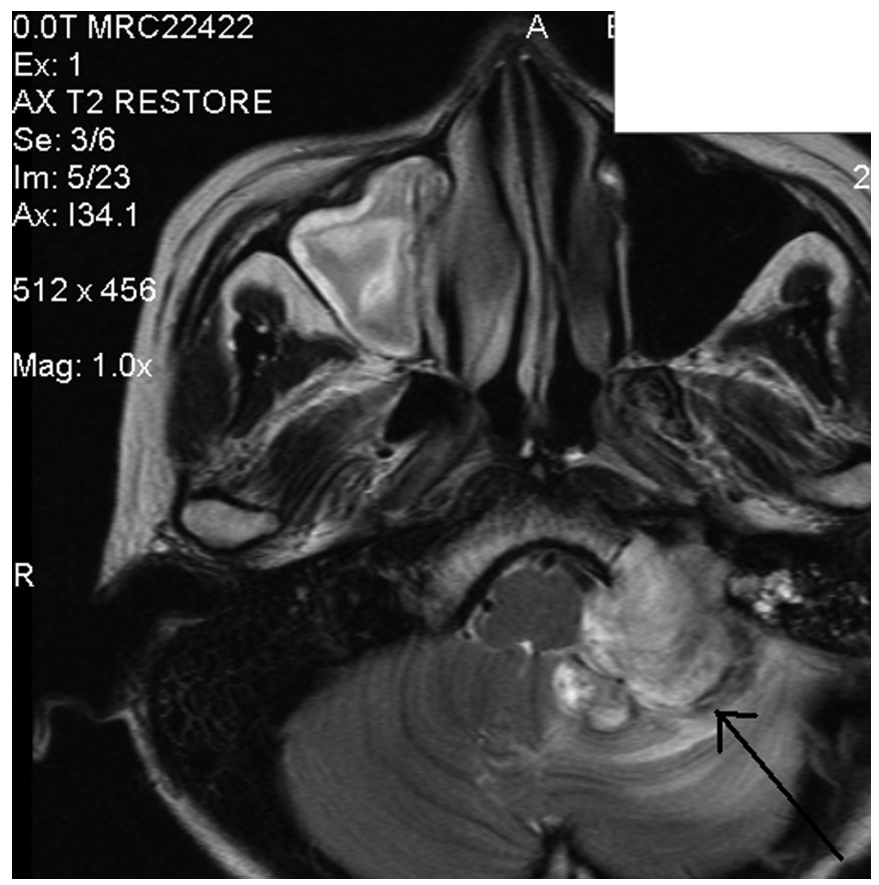

Figure 5: MR image showing recurrent lesion with extension into cerebellum and brainstem. Note shift and hydrocephalus. Lesion measures $37 \times 41 \times 42 \mathrm{~mm}$. Image was taken February 2008.

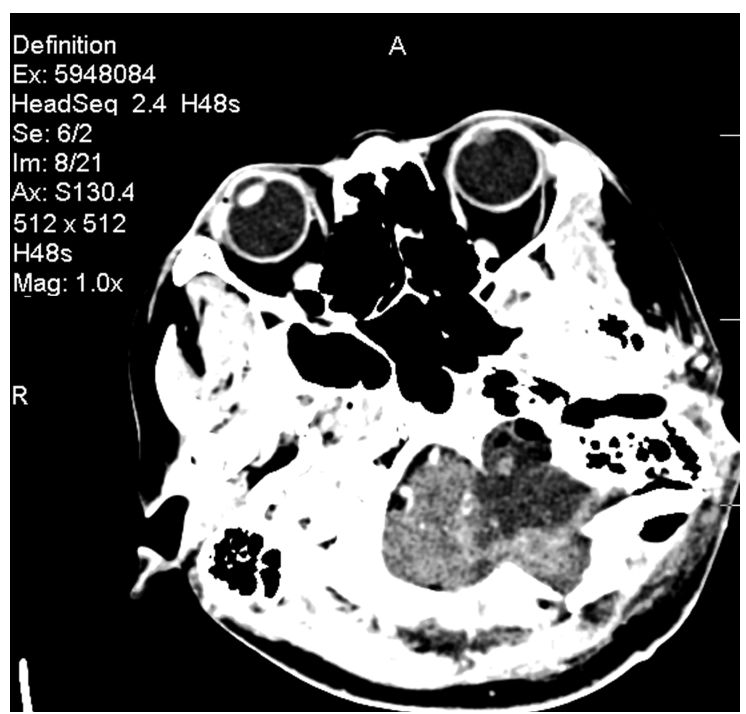

Figure 4: Immediate post operative CT scan demonstrating successful gross total resection. Note the lack of residual enhancing tumor. Image was taken January 2008.

focally pronounced with sparse large atypical tumor cells. There was a well defined, benign mature ganglion cell component that was highlighted by an NSE immunoperoxidase study. There were also areas with rhabdoid characteristic displaying cells with signet ring appearance of nuclei and eosinophillic perinuclear cytoplasm. Areas of calcification, possibly representing osseous metaplasia, were also seen. A portion of the cells stained positive for $\mathrm{p} 53$. There were well defined and distinct areas staining for s-100. Many tumor cells also stained for vimentin. This tumor was felt to be consistent with a high grade malignant peripheral

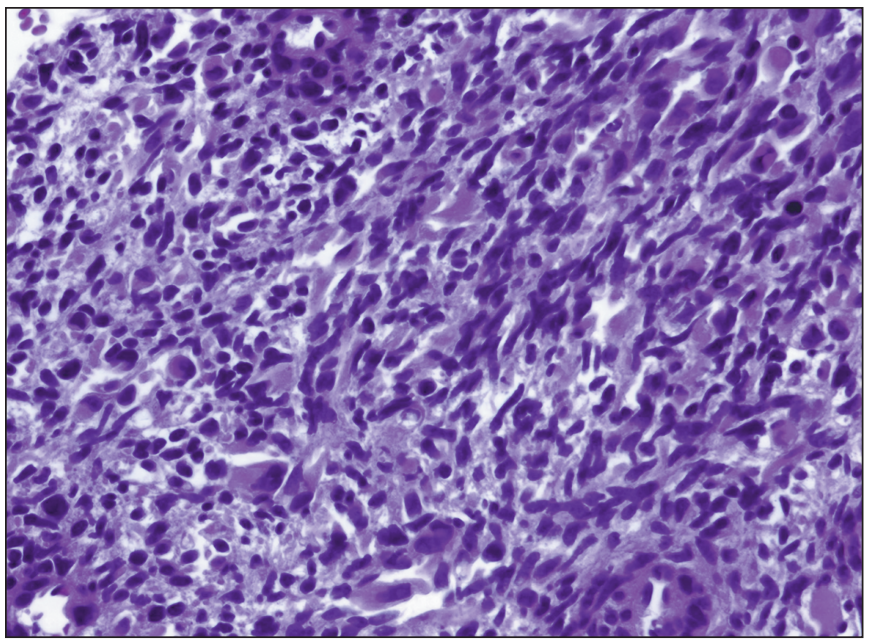

Figure 6: H\&E Immunoperoxidase staining. 200x true magnification. Cellular component of lesions demonstrating small blue cell tumor appearance with eccentric nuclei and prominent nucleolus. Consistent with high grade malignancy. Specimen is dated January 2008. 


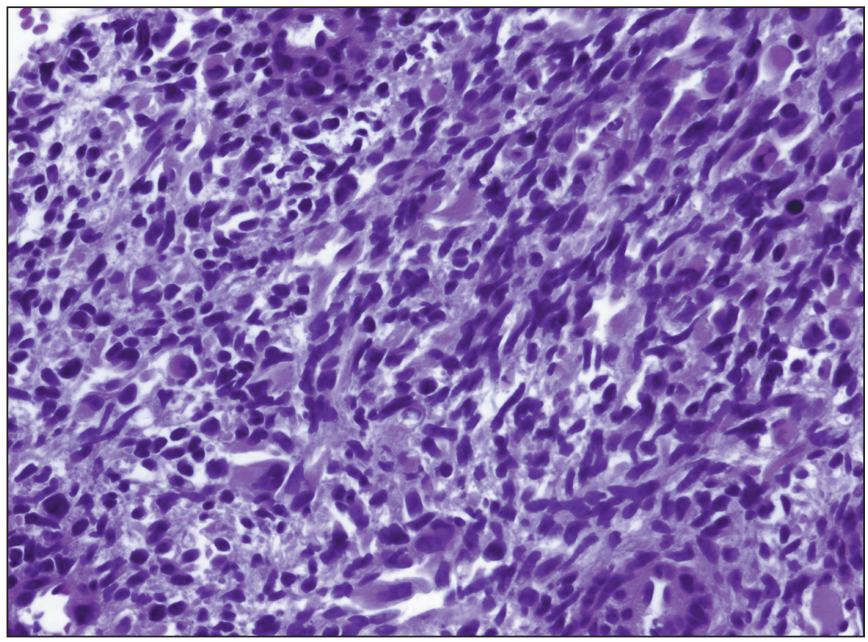

Figure 7: NSE immunoperoxidase stain. 200x true magnification. This image demonstrates the focal ganglion cell elements in tumor (highlighted with arrow), confirming the diagnosis of ganglioneuroma. Specimen is dated January 2008.

nerve sheath tumor (MPNST) arising from a ganglioneuroma (Figures 6-9).

\section{Review of the literature}

Two separate literature reviews were carried out. First, a literature review of all previous cases of MPNST arising from a ganglioneuroma was carried out. The search terms "Malignant Peripheral Nerve Sheath Tumor" or "MPNST" and "ganglioneuroma" were entered into searchable databases (Pubmed and Google Scholar) which yielded 11 publications

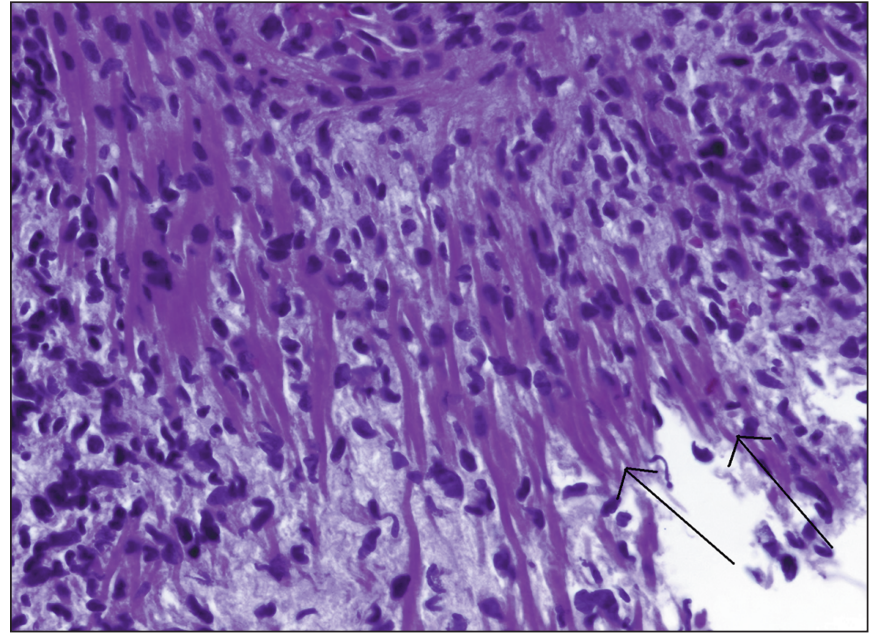

Figure 8: H\&E immunoperoxidase stain. 200x true magnification. This slide demonstrates isolated focal myoblastic features (highlighted with arrows), suggesting high grade malignancy, consistent with MPNST. Specimen is dated January 2008.

with 13 patients. There were approximately as many females as males (5:6) and presented on average at 15 years-of-age. None had a history of any genetic predisposition, while five had previous radiation therapy a mean of 160 months prior (Table $1)^{3-13}$.

A second literature review of stereotactic radiosurgery associated or induced lesions was conducted. Using the search terms "radiosurgery" and "secondary malignancy" or "malignant degeneration" or "complication" or "secondary neoplasm" entered into the aforementioned databases, a total of 28

Table 1: MPNST in Ganglioneuroma ${ }^{3-13}$

\begin{tabular}{|c|c|c|c|c|c|c|}
\hline $\begin{array}{l}\text { Author } \\
\text { De Chadarevian }\end{array}$ & Year & $\begin{array}{l}\text { Age of } \\
\text { patient } \\
\text { (years) }\end{array}$ & Sex & $\begin{array}{c}\text { Time after } \\
\text { radiation to } \\
\text { development } \\
\text { of MPNST }\end{array}$ & $\begin{array}{c}\text { Previous } \\
\text { Radiation }\end{array}$ & $\begin{array}{c}\text { Genetic } \\
\text { predisposition }\end{array}$ \\
\hline $\mathrm{JP}$ et $\mathrm{al}^{3}$ & 2004 & 6 & M & na & $\mathrm{n}$ & $\mathrm{n}$ \\
\hline Navarro $\mathrm{O}$ et $\mathrm{al}^{4}$ & 2000 & 1.5 & na & 144 & $\mathrm{y}$ & $\mathrm{n}$ \\
\hline Navarro $\mathrm{O}$ et $\mathrm{al}^{4}$ & 2000 & 0.5 & na & 144 & $\mathrm{y}$ & $\mathrm{n}$ \\
\hline $\begin{array}{l}\text { Drago } \mathrm{G} \mathrm{et} \text { al } \\
\text { Grippari JL et } \\
\mathrm{al}^{6}\end{array}$ & 1997 & 11.5 & $\mathrm{M}$ & na & $\mathrm{n}$ & $\mathrm{n}$ \\
\hline Ghali VS et al ${ }^{7}$ & 1992 & na & M & na & $\mathrm{n}$ & $\mathrm{n}$ \\
\hline Damiani S et $\mathrm{al}^{8}$ & 1991 & 18 & $\mathrm{~F}$ & na & $\mathrm{n}$ & $\mathrm{n}$ \\
\hline $\begin{array}{l}\text { Banks E et al }{ }^{9} \\
\text { Fletcher CD et }\end{array}$ & 1989 & 15 & M & na & $\mathrm{n}$ & $\mathrm{n}$ \\
\hline 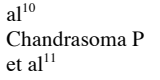 & 1988 & 32 & M & na & $\mathrm{n}$ & $\mathrm{n}$ \\
\hline Ricci A Jr et al ${ }^{12}$ & 1984 & 10 & F & 99 & $\mathrm{y}$ & $\mathrm{n}$ \\
\hline $\begin{array}{l}\text { Ricci A Jr et al }{ }^{12} \\
\text { Keller SM et } \\
\mathrm{al}^{13}\end{array}$ & 1984 & 18 & $\mathrm{~F}$ & 204 & $\mathrm{y}$ & $\mathrm{n}$ \\
\hline
\end{tabular}

na=not available; $m=$ male; $f=$ female; $n=n o ; y=y e s$



Figure 9: MIB -1 Immunoperoxidase study. 200x true magnification. This slide shows the dramatic variability of mitotic activity ranging from pronounced to modest, suggestive of the varied benign and malignant cellular components comprising this lesion. The amount of staining corresponds to areas of increased mitotic activity. Specimen is dated January 2008. 
Table 2: Secondary lesions after radiosurgery ${ }^{14-40}$

\begin{tabular}{|c|c|c|c|c|c|c|c|}
\hline Author & $\begin{array}{c}\text { Year of } \\
\text { Publication }\end{array}$ & $\begin{array}{l}\text { Age at initial } \\
\text { presentation }\end{array}$ & Sex & Primary Lesion & $\begin{array}{c}\text { Radiosurgery associated } \\
\text { lesion } \\
\text { Malignant Peripheral Nerve }\end{array}$ & $\begin{array}{l}\text { Time to second } \\
\text { lesion (months) }\end{array}$ & $\begin{array}{c}\text { Genetic } \\
\text { predisposition }\end{array}$ \\
\hline Tu et al. & present case & 34 & $\mathrm{~F}$ & Ganglioneuroma & Sheath Tumor (MPNST) & 104 & $\mathrm{Na}$ \\
\hline Wang $\mathrm{K}$ et $\mathrm{al}^{14}$ & 2012 & 7 & na & Meningioma & Ependymoma & na & $\mathrm{Na}$ \\
\hline Lee HS et al ${ }^{15}$ & 2012 & 47 & $\mathrm{~F}$ & $\begin{array}{c}\text { Meningioma } \\
\text { Vestibular }\end{array}$ & $\begin{array}{c}\text { GBM } \\
\text { Malignant fibrous }\end{array}$ & 58 & $\mathrm{Na}$ \\
\hline Schmitt WR et al ${ }^{16}$ & 2011 & 51 & M & Schwannoma (VS) & histiocytoma & 90 & $\begin{array}{c}\mathrm{Na} \\
\text { Neurofibromatosis }\end{array}$ \\
\hline Park YS et al ${ }^{18}$ & 2011 & 21 & $\mathrm{~F}$ & Pineocytoma & cavernous malformation & 24 & $\mathrm{Na}$ \\
\hline Akamatsu $Y$ et al ${ }^{19}$ & 2010 & 67 & $\mathrm{~F}$ & VS & MPNST & 96 & $\mathrm{Na}$ \\
\hline Carlson ML et $\mathrm{al}^{20}$ & 2010 & 12 & $\mathrm{~F}$ & VS & Rhabdomyosarcoma & 120 & NF2 \\
\hline Demetriades AK et $\mathrm{al}^{21}$ & 2010 & 27 & M & VS & Anaplastic sarcoma & 120 & $\mathrm{Na}$ \\
\hline Sasagawa et $\mathrm{al}^{22}$ & 2009 & 35 & M & VS & Cavernous malformation & 120 & $\mathrm{Na}$ \\
\hline Muracciole $\mathrm{X}$ and Regis $\mathrm{J}^{23}$ & 2008 & $\mathrm{Na}$ & $\mathrm{Na}$ & $\mathrm{Na}$ & Unknown & Unknown & $\mathrm{Na}$ \\
\hline Balasubramaniam A et $\mathrm{al}^{24}$ & 2007 & 60 & $\mathrm{~F}$ & VS & GBM & 60 & $\mathrm{Na}$ \\
\hline Berman EL et $\mathrm{al}^{25}$ & 2007 & 34 & $\mathrm{~F}$ & AVM & GBM & 108 & $\mathrm{Na}$ \\
\hline Iwai $\mathrm{Y}$ et $\mathrm{al}^{26}$ & 2007 & 37 & M & Metastasis (lung ca) & Cavernous malformation & 24 & $\mathrm{Na}$ \\
\hline Sheehan $\mathrm{J}$ et $\mathrm{al}^{27}$ & 2006 & 7 & M & AVM & Meningioma & 120 & $\mathrm{Na}$ \\
\hline Sheehan $\mathrm{J}$ et $\mathrm{al}^{27}$ & 2006 & 12 & $\mathrm{~F}$ & $\begin{array}{c}\text { AVM } \\
\text { Metastasis }\end{array}$ & Meningioma & 120 & $\mathrm{Na}$ \\
\hline McIiverJI and Pollock BE ${ }^{28}$ & 2004 & 43 & $\mathrm{~F}$ & (melanoma) & Anaplastic astrocytoma & 64 & $\mathrm{Na}$ \\
\hline Sanno $\mathrm{N}$ et $\mathrm{al}^{29}$ & 2004 & 53 & $\mathrm{~F}$ & Meningioma & Osteosarcoma & 48 & $\mathrm{Na}$ \\
\hline Wilkinson JS et al ${ }^{30}$ & 2004 & 53 & M & VS & MPNST & 84 & $\mathrm{Na}$ \\
\hline Loeffler JS ${ }^{31}$ & 2003 & 41 & M & Pituitary tumour & Meningioma & 192 & $\mathrm{Na}$ \\
\hline Loeffler JS $S^{31}$ & 2003 & 53 & M & Pituitary tumour & VS & 228 & $\mathrm{Na}$ \\
\hline Salvati $\mathrm{M}$ et $\mathrm{al}^{32}$ & 2003 & 79 & $\mathrm{~F}$ & Cavernous angioma & GBM & 156 & $\mathrm{Na}$ \\
\hline Bari ME et al ${ }^{33}$ & 2002 & 28 & $\mathrm{~F}$ & VS & MPNST & 42 & NF2 \\
\hline Shin $\mathrm{M}$ et $\mathrm{al}^{34}$ & 2002 & 26 & $\mathrm{~F}$ & VS & MPNST & 72 & $\mathrm{Na}$ \\
\hline Shamisa $\mathrm{A}$ et $\mathrm{al}^{37}$ & 2001 & 57 & $\mathrm{~F}$ & VS & GBM & 90 & $\mathrm{Na}$ \\
\hline Thomsen $\mathbf{J}$ et $\mathrm{al}^{38}$ & 2000 & 19 & $\mathrm{~F}$ & VS & Meningiosarcoma & 72 & NF2 \\
\hline Bari ME et $\mathrm{al}^{33}$ & 2000 & 28 & $\mathrm{~F}$ & VS & MPNST & 48 & $\mathrm{Na}$ \\
\hline Yu JS et $\mathrm{al}^{39}$ & 2000 & 63 & $\mathrm{~F}$ & Meningioma & GBM & 84 & $\mathrm{Na}$ \\
\hline Comey $\mathrm{CH}$ et $\mathrm{al}^{40}$ & 1998 & 44 & M & VS & Triton tumour (sarcoma) & 60 & $\mathrm{Na}$ \\
\hline
\end{tabular}

na=not available; VS=vestibular schwannoma; AVM=arteriovenous malformation; GBM=glioblastoma multiforme

publications with 31 patients were found (Table 2) ${ }^{14-40}$. Two reports were inaccessible in full leaving 28 patients with complete records and three with partial records. The average age on initial presentation with a primary lesion was 37.5 years old and time to development of a secondary lesion was 86.9 months after the first radiosurgery treatment. There was a predisposition for female patients (1.6:1 F:M). The most common primary pathology treated was vestibular schwannoma followed by arteriovenous malformations and metastases. The most common secondary lesions were MPNST and glioblastoma multiforme (GBM)/high grade astrocytic tumors (Table 3). Location of recurrence was divided into occurring in the same location as the primary lesion, occurring adjacent to the primary lesion, and remote to the previous lesion (Table 4). Over half of the secondary lesions occurred within the same location as the primary lesion while the remainder occurred in adjacent and remote areas. Only a small proportion of cases $(n=4)$ comprised patients with known genetic predispositions for oncogenesis (ie. NF2).

\section{DiscuSSION}

Ganglioneuromas are rare, histologically benign tumors that arise from neural crest cells of the sympathetic nervous system. They are most commonly found in the mediastinum and retroperitoneum with none previously documented to arise from the jugular foramen ${ }^{41,42}$. There is a slight female preponderance and are more common in the pediatric population ${ }^{43}$. There exists a propensity for occurrence in specific genetic syndromes including the neurofibromatoses ${ }^{43}$. Ganglioneuromas may arise de novo or from maturation of neuroblastoma/ ganglioneuroblastoma during chemotherapy or radiation therapy ${ }^{44}$. 
Table 3: Summary of radiosurgery associated lesions

\begin{tabular}{|c|c|c|c|c|}
\hline $\begin{array}{l}\text { Primary } \\
\text { lesions }\end{array}$ & $\mathbf{n}$ & $\begin{array}{c}\text { Secondary } \\
\text { Lesions }\end{array}$ & $\mathbf{n}$ & $\begin{array}{l}\text { Average time } \\
\text { to secondary } \\
\text { lesion (months) }\end{array}$ \\
\hline VS & 15 & $\begin{array}{l}\text { GBM/high } \\
\text { grade astrocytic } \\
\text { tumour }\end{array}$ & 8 & 86.875 \\
\hline meningioma & 4 & MPNST & 8 & 72.75 \\
\hline AVM & 4 & sarcoma & 6 & 85 \\
\hline $\begin{array}{l}\text { Metastases } \\
\text { pituitary }\end{array}$ & 2 & $\begin{array}{l}\text { meningioma } \\
\text { cavernous }\end{array}$ & 3 & 144 \\
\hline tumour & 2 & $\begin{array}{l}\text { malformation } \\
\text { low grade }\end{array}$ & 2 & 72 \\
\hline cavernous & & astrocytic & & \\
\hline angioma & 1 & $\begin{array}{l}\text { tumour } \\
\text { vestibular }\end{array}$ & 1 & na \\
\hline pineocytoma & 1 & schwannoma & 1 & na \\
\hline ganglioneuroma & 1 & & & \\
\hline
\end{tabular}

na=not available; $\mathrm{m}=$ male; $\mathrm{f}=$ female; $\mathrm{n}=\mathrm{no} ; \mathrm{y}=\mathrm{yes}$

These tumors most often present with mass effect although may also secrete catecholamines or vasoactive intestinal peptide (VIP) causing hypertension and flushing ${ }^{44,45}$. Metastases to lymph nodes have been rarely described, although these have been attributed to maturation of a more malignant tumor that has already spread ${ }^{44,45}$. Surgical excision is curative and the prognosis of even incomplete resection remains excellent ${ }^{46}$. Adjunctive treatments such as stereotactic radiosurgery and chemotherapy have been described, but given the infrequency of its use, no established protocols exist in the literature ${ }^{3,47}$.

The development of intracranial Malignant Peripheral Nerve Sheath Tumors after stereotactic radiosurgery or radiation therapy is an uncommon although described event in the literature. These are aggressive sarcomatous spindle cell tumors with non distinctive morphologic features making immunohistochemistry crucial to the diagnosis ${ }^{3}$. The cell of origin is unknown, although is thought to be schwannian from electron microscopy and immunohistochemical studies ${ }^{12}$. Mitoses are usually abundant, and about $15 \%$ of these will also contain metaplastic tissues such as cartilage or bone ${ }^{3,12}$. Most MPNST arise from degeneration of lower grade lesions; this event most commonly occurs in the setting of neurofibromatoses ${ }^{3}$. Only $10 \%$ of cases are associated with a history of prior radiation treatement ${ }^{3}$. The delayed development of MPNST from a ganglioneuroma in particular is furthermore an exceedingly rare event- only 13 patients were found during our review (Table 1). All occurred in either the abdomen or thoracic cavity. The rarity of this condition may reflect the baseline infrequence of ganglioneuromas. Interestingly, $38 \%$ of patients had previous history of radiation therapy. Whether this finding reflects a predisposition of ganglioneuromas for malignant degeneration in the context of radiation is unclear; however the outcomes after development of an MPNST are poor regardless of the etiology and are comparable to other soft tissue sarcomas ${ }^{3}$.
Table 4: Location relative to primary lesion

\begin{tabular}{lc} 
Location of secondary location & $\mathbf{n}=\mathbf{3 0}$ \\
Same & 17 \\
Adjacent & 7 \\
Remote & 6 \\
\hline
\end{tabular}

This case does call into question the safety of radiation based treatments in the management of histologically benign intracranial neoplasms. A recognized potential complication has been the development of de novo neoplasms. This risk is not well understood with radiosurgery and published opinions have been controversial $^{31,32,48}$. Since the first report in $1998^{39}$, there has been a steady stream of published radiosurgery associated malignancies (Table 2). The most common primary lesions have been histologically benign tumors. The reason for this phenomenon may reflect the shorter life expectancies of patients treated for metaststatic or high grade neoplasms thus precluding the delayed development of a secondary lesion. Furthermore, the demographics of these patients is biased towards the nearly half of secondary malignancies occurring in patients treated for vestibular schwannoma.

The potential predisposing factors to radiation induced malignancies are difficult to discern from a study as small as this with such a heterogeneous population. The most common modality of radiosurgery associated malignancy was gamma knife surgery, although cases were also reported with linear accelerator and proton beam systems. The location of the secondary lesion was found in the location of the previous lesion or in adjacent areas in $57 \%$ and $23 \%$ of cases respectively. In comparison $20 \%$ of cases developed in areas remote from the primary target site (Table 4). This occurrence does speak to the potential collateral injury that surrounding regions of eloquent tissue may suffer from focal radiation. Surprisingly, only a small number of patients with a known genetic predisposition were found to have developed a radiation associated lesion. This finding may downplay the contribution of familial syndromes in the development of specifically radiosurgery associated malignancy. This data may also suggest the cautious use of radiosurgery in young patients with benign lesions given the long remaining life expectancies. Operative or conservative therapy may be more amenable in these patients. A major difficulty in managing these patients is the lack of adequate tools to identify patients at risk for developing radiation associated lesions. Inherent patient diversity, long time delay, as well as the lack of obvious predisposing factors has made identification of higher risk patients challenging, especially in light of the overall paucity of its occurrence. 


\section{Conclusion}

This report comprises the first description of a ganglioneuroma occurring within the jugular foramen, as well as adding to the limited number of reports depicting delayed MPNST in a ganglioneuroma. Complicating this case is the potential role stereotactic radiosurgery may have had in the degeneration of this lesion. The pathologic diagnosis of this tumor was determined only after a delayed resection, leading one to consider whether other aberrantly categorized lesions of this nature have been treated similarly. Indeed, it is not with the standard of practice to histologically confirm what are felt to be ostensibly benign lesions with supposedly characteristic imaging and treatment response features. Furthermore, the actual risk of malignant degeneration in associated with radiosurgery remains uncertain, although it will be better improved with raised awareness. This case and its predecessors illustrate that even the most unexpected complications can occur and emphasizes the need for vigilant follow up of all patients. The authors feel that it is important to document these allegedly rare events as, with enhanced awareness, the medical community may better tailor treatment for a given patient's risk factors and needs.

\section{REFERENCES}

1. Rhoton AL. Jugular foramen. Neurosurg. 2000 Sep;47(3 Suppl): S267-85.

2. Ramina R, Maniglia JJ, Fernandes YB, et al. Jugular foramen tumors: diagnosis and treatment. Neurosurg Focus. 2004 Aug; 17(2):E5

3. De Chadarévian J-P, MaePascasio J, Halligan GE, et al. Malignant peripheral nerve sheath tumor arising from an adrenal ganglioneuroma in a 6-year-old boy. Ped Dev Path. 2004;7(3): 277-84.

4. Navarro O, Nunez-Santos E, Daneman A, Faria P, Daltro P. Malignant peripheral nerve-sheath tumor arising in a previously irradiated neuroblastoma: report of 2 cases and a review of the literature. Ped Rad. 2000;30(3):176-80.

5. Drago G, Pasquier B, Pasquier D, et al. Malignant peripheral nerve sheath tumor arising in a "de novo" ganglioneuroma: a case report and review of the literature. Med Ped Onc. 1997;28(3): 216-22.

6. Grippari JL, Neveux Y, Arborio M, et al. [Tumor of the peripheral nerve sheath with rhabdomyoblastic differentiation arising in a ganglioneuroma: neurilemmoma? A fortuitously detected case]. Ann De Path. 1996;16(2):128-32.

7. Ghali VS, Gold JE, Vincent RA, Cosgrove JM. Malignant peripheral nerve sheath tumor arising spontaneously from retroperitoneal ganglioneuroma: a case report, review of the literature, and immunohistochemical study. Hum Path. 1992;23 (1):72-5.

8. Damiani S, Manetto V, Carrillo G, Di Blasi A, Nappi O, Eusebi V. Malignant peripheral nerve sheath tumor arising in a "de novo" ganglioneuroma. A case report. Tumori. 1991;77(1):90-3.

9. Banks E, Yum M, Brodhecker C, Goheen M. A malignant peripheral nerve sheath tumor in association with a paratesticular ganglioneuroma. Cancer. 1989;64(8):1738-42.

10. Fletcher CD, Fernando IN, Braimbridge M V, McKee PH, Lyall JR. Malignant nerve sheath tumour arising in a ganglioneuroma. Histopath. 1988;12(4):445-8.

11. Chandrasoma P, Shibata D, Radin R, Brown LP, Koss M. Malignant peripheral nerve sheath tumor arising in an adrenal ganglioneuroma in an adult male homosexual. Cancer. 1986;57 (10):2022-5.

12. Ricci A, Parham DM, Woodruff JM, Callihan T, Green A, Erlandson RA. Malignant peripheral nerve sheath tumors arising from ganglioneuromas. Am J Surg Path. 1984;8(1):19-29.
13. Keller SM, Papazoglou S, McKeever P, Baker A, Roth JA. Late occurrence of malignancy in a ganglioneuroma 19 years following radiation therapy to a neuroblastoma. J Surg Onc. 1984;25(4):227-31.

14. Wang K, Pan L, Che X, Lou M. Gamma knife surgery-induced ependymoma after the treatment of meningioma - a case report. Neurol I Neurochir Pol. 2013;46(3):294-6.

15. Lee HS, Kim JH, Lee J-I. Glioblastoma following radiosurgery for meningioma. J Kor Neurosurg Soc. 2012;51(2):98-101.

16. Schmitt WR, Carlson ML, Giannini C, Driscoll CLW, Link MJ. Radiation-induced sarcoma in a large vestibular schwannoma following stereotactic radiosurgery: case report. Neurosurg. 2011;68(3):E840-6; discussion E846.

17. Tanbouzi Husseini S, Piccirillo E, Taibah A, Paties CT, Rizzoli R, Sanna M. Malignancy in vestibular schwannoma after stereotactic radiotherapy: a case report and review of the literature. Laryngyscope. 2011;121(5):923-8.

18. Park YS, Kim SH, Chang JH, Chang JW, Park YG. Radiosurgery for radiosurgery-induced cavernous malformation. World Neurosurg. 2011;75(1):94-8.

19. Akamatsu Y, Murakami K, Watanabe M, Jokura H, Tominaga T. Malignant peripheral nerve sheath tumor arising from benign vestibular schwannoma treated by gamma knife radiosurgery after two previous surgeries: a case report with surgical and pathological observations. World Neurosurg. 2010;73(6):751-4.

20. Carlson ML, Babovic-Vuksanovic D, Messiaen L, et al. Radiationinduced rhabdomyosarcoma of the brainstem in a patient with neurofibromatosis type 2. J Neurosurg. 2010;112(1):81-7.

21. Demetriades AK, Saunders N, Rose P, et al. Malignant transformation of acoustic neuroma/vestibular schwannoma 10 years after gamma knife stereotactic radiosurgery. Skull Base. 2010;20(5):381-7.

22. Sasagawa Y, Akai T, Itou S, Iizuka H. Gamma knife radiosurgeryinduced cavernous hemangioma: case report. Neurosurg. 2009; 64(5):E1006-7; discussion E1007.

23. Muracciole X, Régis J. Radiosurgery and carcinogenesis risk. Prog Neurol Surg. 2008;21:207-13.

24. Balasubramaniam A, Shannon P, Hodaie M, Laperriere N, Michaels H, Guha A. Glioblastoma multiforme after stereotactic radiotherapy for acoustic neuroma: case report and review of the literature. Neuro Oncol. 2007;9(4):447-53.

25. Berman EL, Eade TN, Brown D, et al. Radiation-induced tumor after stereotactic radiosurgery for an arteriovenous malformation: case report. Neurosurg. 2007;61(5):E1099; discussion E1099.

26. Iwai Y, Yamanaka K, Yoshimura M. Intracerebral cavernous malformation induced by radiosurgery. Case report. Neurolog Med-Chirurg. 2007;47(4):171-3.

27. Sheehan J, Yen CP, Steiner L. Gamma knife surgery-induced meningioma. Report of two cases and review of the literature. J Neurosurg. 2006;105(2):325-9.

28. McIver JI, Pollock BE. Radiation-induced tumor after stereotactic radiosurgery and whole brain radiotherapy: case report and literature review. J Neuro-Onc. 2004;66(3):301-5.

29. Sanno N, Hayashi S, Shimura T, Maeda S, Teramoto A. Intracranial osteosarcoma after radiosurgery--case report. Neurol Med Chir (Tokyo). 2004;44(1):29-32.

30. Wilkinson JS, Reid H, Armstrong GR. Malignant transformation of a recurrent vestibular schwannoma. J Clin Path. 2004;57(1): 109-10.

31. Loeffler JS, Niemierko A, Chapman PH. Second tumors after radiosurgery: tip of the iceberg or a bump in the road? Neurosurg. 2003;52(6):1436-40; discussion 1440-2.

32. Salvati M, Frati A, Russo N, et al. Radiation-induced gliomas: report of 10 cases and review of the literature. Surg Neur. 2003; 60(1):60-7; discussion 67.

33. Bari ME, Forster DMC, Kemeny AA, Walton L, Hardy D, Anderson JR. Malignancy in a vestibular schwannoma. Report of a case with central neurofibromatosis, treated by both stereotactic radiosurgery and surgical excision, with a review of the literature. Br J Neurosurg. 2002;16(3):284-9. 
34. Shin M, Ueki K, Kurita H, Kirino T. Malignant transformation of a vestibular schwannoma after gamma knife radiosurgery. Lancet. 2002;360(9329):309-10.

35. Kaido T, Hoshida T, Uranishi R, et al. Radiosurgery-induced brain tumor. Case report. J Neurosurg. 2001;95(4):710-13.

36. Hanabusa K, Morikawa A, Murata T, Taki W. Acoustic neuroma with malignant transformation. Case report. J Neurosurg. 2001; 95(3):518-21.

37. Shamisa A, Bance M, Nag S, et al. Glioblastoma multiforme occurring in a patient treated with gamma knife surgery. Case report and review of the literature. J Neurosurg. 2001;94(5): 816-21.

38. Thomsen J, Mirz F, Wetke R, Astrup J, Bojsen-Møller M, Nielsen E. Intracranial sarcoma in a patient with neurofibromatosis type 2 treated with gamma knife radiosurgery for vestibular schwannoma. Am J Otol. 2000;21(3):364-70.

39. Yu JS, Yong WH, Wilson D, Black KL. Glioblastoma induction after radiosurgery for meningioma. Lancet. 2000;356(9241): 1576-7.

40. Comey CH, McLaughlin MR, Jho HD, Martinez AJ, Lunsford LD. Death from a malignant cerebellopontine angle triton tumor despite stereotactic radiosurgery. Case report. J Neurosurg. 1998;89(4):653-8.
41. Leonardis M, Sperb D, Alster C, Campisi C, Herter NT. Ganglioneuroma of the neck, masquerading as a goiter. Eur $\mathrm{J}$ Surg Onc. 2003;29(10):929-30.

42. Ozluoglu LN, Yilmaz I, Cagici CA, Bal N, Erdogan B. Ganglioneuroma of the internal auditory canal: a case report. Aud Neuro-Otology. 2007;12(3):160-4.

43. Forsythe A, Volpe J, Muller R. Posterior mediastinal ganglioneuroma. Radiograph. 2013;24(2):594-7.

44. Lonergan GJ, Schwab CM, Suarez ES, Carlson CL. Neuroblastoma, ganglioneuroblastoma, and ganglioneuroma: radiologic-pathologic correlation. Radiograph. 2013;22(4): 911-34.

45. Geoerger B, Hero B, Harms D, Grebe J, Scheidhauer K, Berthold F. Metabolic activity and clinical features of primary ganglioneuromas. Cancer. 2001;91(10):1905-13.

46. De Bernardi B, Gambini C, Haupt R, et al. Retrospective study of childhood ganglioneuroma. J Clin Onc. 2008;26(10):1710-16.

47. Freeman CR, Souhami L, Caron JL, et al. Stereotactic external beam irradiation in previously untreated brain tumors in children and adolescents. Med Ped Onc. 1994;22(3):173-80.

48. Nagy G, Razak A, Rowe JG, et al. Stereotactic radiosurgery for deep-seated cavernous malformations: a move toward more active, early intervention. Clinical article. J Neurosurg. 2010;113 (4):691-9. 